\title{
Economic and Legal Policy of the State in the Field of Digital Economy
}

\author{
Oksana M. Vinnyk ${ }^{1, *}$, Dmytro V. Zadykhaylo ${ }^{2}$, Olena M. Honcharenko ${ }^{3}$, \\ Olga V. Shapovalova ${ }^{4}$ and Nino B. Patsuriia ${ }^{5}$
}

\begin{abstract}
${ }^{1}$ Departmentof International Private and Comparative Law, Academician F.H. Burchak Scientific and Research Institute of Private Law and Entrepreneurship of the National Academy of Legal Sciences of Ukraine, Kyiv, Ukraine

${ }^{2}$ Department of Economic Law, Yaroslav Mudryi National Law University, Kharkiv, Ukraine

${ }^{3}$ Department of Legal Support of the Market Economy, Academician F.H. Burchak Scientific and Research Institute of Private Law and Entrepreneurship of the National Academy of Legal Sciences of Ukraine, Kyiv, Ukraine

${ }^{4}$ Department of Business Law, Volodymyr Dahl East Ukrainian National University, Severodonetsk, Ukraine

${ }^{5}$ Department of Commercial Law and Commercial Process, Taras Shevchenko National University of Kyiv, Kyiv, Ukraine
\end{abstract}

\begin{abstract}
Digitalisation of the economic sphere of Ukraine is one of the priority areas of social development, which should be reflected in the economic and legal policy of the state. Therewith, a considerable gap exists in the statutory consolidation of the fundamental principles of such a policy, in particular the lack of relevant provisions on the digital transformation of the economy in the Commercial Code of Ukraine. Despite the fact that the state has adopted some acts on the development of the digital economy, there are significant gaps in the legislation, especially with regard to the role of digitalisation in the economic and legal policy of the state. The purpose of the study is a theoretical analysis of the general principles of such a policy in the modern period. As a result, the impact on the economic and legal policy of the state of the process of digitalisation of the economic sphere of the country is determined. The necessity of co-regulation is substantiated, which constitutes a combination of state regulation with self-regulation by participants of digitallytargeted markets. The role of digital resources (on the example of public registers) and electronic financial services is analysed. It is established that the modern legal support of the digital economy needs to be reformed, first of all, by supplementing the Commercial Code of Ukraine with provisions on digitalisation, including the relevant direction of economic and legal policy of the state. The results of the study have a scientific novelty, as they fill the gap in the coverage of the role of the state in the process of digitalisation of the economy.
\end{abstract}

Keywords: Digitalisation, economic relations, public registers, co-regulation, financial services.

\section{INTRODUCTION}

The digitalisation of the main spheres of social life, including the economy, is rapidly accelerating, which is facilitated by the situation with the coronavirus pandemic and related quarantine measures. The current unprecedented success of digitalisation is conditioned by its many advantages, including the ability to communicate (including both social and business interaction) online, advertise business results, search and order goods (works, services) and pay for them remotely, distance learning, etc. Therewith, these benefits are used not only by honest members of society but also by people who want to take advantage of digitalisation to gain undeserved benefits, basic theft, do other harm not only to citizens but also to businesses, government agencies and international

*Address correspondence to this author at the Academician F.H. Burchak Scientific and Research Institute of Private Law and Entrepreneurship of the National Academy of Legal Sciences of Ukraine, Kyiv, Ukraine;

Tel: (044) 28635 93; E-mail: vinnyk4@tanu.pro organisations, the number of cyberattacks on which is constantly growing.

Under these conditions, the role of the state as an exponent and bearer of society's interests in the digitalisation process is growing, although in real life there is a significant lag in the state's response to ambiguous results of digital technologies with their inherent advantages and risks. However, at the level of science (including the legal one) this issue remains understudied. The prevailing view among researchers is the dominance of the advantages of digitalisation over its risks and, accordingly, the priority of selfregulation by participants in digitalised markets over ineffective government regulation (Depscott and Depscott 2019; Steiner 2018). Only some studies emphasise the need to strengthen the efficiency and social orientation of state, including regulatory, regulation of the digital economy, taking into account the existing and potential benefits and risks of digitalisation (Heeks 2018; Vinnyk, Shapovalov,

() 2021 Lifescience Global 
Patsuriia et al. 2020). Usually, scientists, raising the problems of the social direction of digitalisation, pay the most attention to the problems of cybersecurity, including in the perspective of using public-private partnerships for this purpose (Rogers 2016). This form of cooperation between government and business is universal in accelerating the digital transformation, as mentioned at the Smart Nation summit (2019).

The problems of the complex solution of legal aspects of the state's economic policy in the field of digital economy relations - both the general principles of such a policy and the specific features of its implementation in individual markets, using certain tools, etc. - remain understudied. Therefore, the purpose of this study is to fill this gap and, accordingly, highlight the general principles of economic and legal policy of the Ukrainian state in the context of digitalisation (impact on such digitalisation policy and related tasks of the strategic and tactical plan), the need for co-regulation (the combination of state regulation with self-regulation of participants of digitalised markets and their self-regulatory organisations), the role of digital resources (on the example of electronic public registers) and electronic financial services in ensuring the civilised nature of the digital economy and digitalisation of public life in general.

\section{GENERAL PRINCIPLES OF ECONOMIC AND LEGAL POLICY OF THE STATE}

In modern economic conditions, when the element of uncertainty of economic development forecasts grows critically, the realism and efficiency of economic and business and legal policy of the state, its certainty with the desired results of economic institutions and the most effective means of achieving such results. Admittedly, the socio-political demand for quality and perfection of national policy, in particular in the economic sphere has grown substantially. On the one hand, this is explained by the process of complicating the very systematics of economic relations of their system-structural factor, the order of functioning of market self-regulation mechanisms, the need to consider numerous public interests, etc. On the other hand, it also happens under the influence of external, ancillary factors, such as security, environmental, socio-humanitarian factors, etc. The very process of harmonising the balance of such public imperatives should be considered as the art of public management.

Thus, the public demand for high-quality "software" of the state's influence on the sphere of economic relations becomes a high-priority political task. In this context, the economic policy of the state can be defined as a form of implementation of its sovereign economic power and relevant functions, which are organisationally institutionalised as a special type and process of activity, which, in turn, comprises relations regarding the development and implementation of officially approved algorithm influence on the content, structure, and dynamics of domestic and foreign economic processes, on the macroeconomic properties of market equilibrium (Zadykhailo 2013). Notably, the economic policy of the state as a political and legal phenomenon has received some legal consolidation in various sources of national legislation, including the Constitution of Ukraine and several laws determining the legal status of the Cabinet of Ministers, government and administration, fundamental principles of national and foreign policy and, most importantly, in the Commercial Code of Ukraine (2020).

The requirement of the legality of the economic policy of the state as a social phenomenon, its functions, mechanism, type of state activity, etc., is based on the provisions of Part 2 of Article 19 of the Fundamental Law, namely that public authorities shall be obliged to act only on the basis, within the powers and in accordance with the procedure established by the Constitution and laws of Ukraine (2020). In this context, it is important that the Commercial Code of Ukraine divides the economic policy of the state according to the areas traditional for its structure. It is symptomatic that its direction as a structural and sectoral policy, which includes industrial, agricultural, construction, and other varieties, is defined in the code in the first place (The Commercial Code of Ukraine 2020). In the context of the emergence of many new segments in the economy, a significant share of which is produced by the introduction of innovative products through the establishment of new markets or through significant changes in the functioning of traditional industries and sectors, it is a structural and sectoral economic policy that is gaining momentum. The national policy, in this case, should define all architecture of functioning of the specified markets with all their structural elements and forms of interaction.

In the instrumental context, the economic policy of the state, including its individual areas, can be implemented through the introduction of legal remedies that collectively establish a special legal regime for the functioning of a particular type of economic relations. It is logical that these legal remedies have their classification, but the most constructive is their division into the segment of economic and production and 
organisational and economic means. The first group includes those that provide features of the legal status of participants in legal relations, the scope of their legal personality, determination of parameters of turnover of objects of legal relations, features of contractual forms and content of binding relations between entities, etc. The second group includes a scope of issues, in particular, the definition of subjects of organisational and economic powers and their economic competence, means of organisational and economic influence, their composition into integrated functional mechanisms, determination of the feasibility of public-private partnership mechanisms, self-regulatory organisations, and establishment of special management regimes. The issue of purely national policy in this area should include the establishment of a special balance of public and private interests, taking into account the diversity of their types and the issue of coexistence.

These aspects of a legal nature, in turn, determine the necessity of the transformational stage of translating the algorithms of economic policy into the instrumental language of economic and legal policy of the state, economic legislation. Notably, along with the use of means of economic and legal regulation, the state also applies tax, legal, environmental, and other means, which together determine the nature of the legal regulation of economic relations. Thus, the economic and legal policy of the state constitutes a component of its legal policy and aims to effectively implement the goals and objectives of state economic policy through direct influence on rule-making and law enforcement processes in the field of management by incorporating the necessary and sufficient economic, legal means, forms and mechanisms of regulation of economic relations into economic legislation. In general, the economic and legal policy of the state is based on the provisions of the constitutional, economic order, the economic policy of the state and scientific economic and legal doctrine. It is consolidated in the content of national programmes for economic development as a mandatory, structural, and instrumental component. This suggests that the economic and legal policy constitutes an imperative conceptual position of the state regarding the directions and content of the further development of legislation, improving the practice of its application, optimising the legal, economic order as such (Zadykhailo 2013).

\section{DIGITALISATION AS AN ASPECT OF NATIONAL ECONOMIC AND LEGAL POLICY}

One of the key issues of economic and legal policy of the state is to solve problems related to the digitalisation of the economic sphere, which in Ukraine, as well as around the world, is accelerating, but there are no relevant provisions in the Commercial Code of Ukraine (2020). This gap is, to some extent, compensated by provisions on national regulation of digitalisation in numerous pieces of legislation (Vinnyk et al. 2020). In particular, the Concept of Development of the Digital Economy and Society of Ukraine for 2018-2020, approved by the relevant act of the Cabinet of Ministers of Ukraine (Order of the Cabinet of Ministers of Ukraine 12.11.2020), stipulates the following:

1. the main purpose of this statutory document: to focus on the implementation of the accelerated scenario of digital development, as the most relevant for Ukraine in terms of challenges, needs and opportunities, which makes provision for various measures: removal of obstacles to the digital economy (legislative, institutional, fiscal, etc.); introduction of incentives and motivations to encourage business and the economy in general to digitalise; creation of demand and development of needs for digitalisation among citizens; digital business development; creation of relevant infrastructures and introduction of new means of stimulation for support and development of innovative activity; launch of new forms of partnership and cooperation for the development of digitalisation in the economic sphere;

2. the content of the development of relations of the digital economy (creation of market incentives, motivations, demand and needs for the use of digital technologies, products and services in the Ukrainian economy to ensure its efficiency, competitiveness and development, growth of high-tech products and welfare) and measures to implement appropriate incentives for digitalisation of the economy, public and social spheres;

3. main goals of digital development (acceleration of economic growth and investment; transformation of economic sectors into competitive and efficient ones; technological and digital modernisation of industry and establishment of high-tech industries; accessibility of benefits and opportunities of the digital world for citizens; fulfilment of human resources, development of digital industries and digital entrepreneurship, etc.); 
4. principles of digitalisation: provision of every citizen with equal access to services, information and knowledge provided based on information and communication and digital technologies (exercise of digital rights of citizens); steering digitalisation towards creation of benefits in various spheres of everyday life, including the economy; implementation of digitalisation for economic growth by increasing the efficiency, productivity and competitiveness of the use of digital technologies; promoting the development of civil society, strengthening the information society and democracy in general; orientation of digitalisation towards international cooperation in order to introduce Ukraine to European and world markets; standardisation as one of the main factors of successful implementation of digital development; increasing the level of trust and security in digitalisation through the effectiveness of information security and cybersecurity, ensuring and protecting the digital rights of citizens and other participants in public life; digitalisation as an object of focus and integrated public administration with relevant tasks of the state aimed at stimulating digitalisation (development of digital infrastructures, digital needs of citizens, and relevant digital competencies, introduction of appropriate incentives and motivations to support digital business and digital economy in general), prevention and containment of negative manifestations of digitalisation by correcting defects of market mechanisms, overcoming institutional and legislative barriers, strengthening the level of security of digital technologies and attracting investment for this purpose);

5. areas of digital development: in general (bridging the digital divide through the development of digital infrastructures; development of digital competencies; implementation of the concept of digital jobs; digitalisation of the real sector of the economy; implementation of digital transformation projects; public safety) and in some areas of public life (e-democracy; ecology and environmental protection, healthcare, public administration, urban life, harmonisation with European and world scientific initiatives).

Therewith, a significant part of the measures outlined in the above-mentioned concept has not been implemented, one of the reasons for which is the low status of this act (approval by Government order, not by law). In addition, there are no strategic measures for the legal support of digitalisation in the form of the Digital Code, as outlined in the draft "Digital Agenda of Ukraine 2020" (developed in 2016). The issue of introducing the use of modern terminology in the digital sphere in accordance with European practices in the form of the relevant law, as provided for by an act of the government upon the approval of the concept, has not been resolved yet. The digital economy is still scattered across various pieces of legislation, as evidenced by the draft laws approved and submitted in autumn 2020 (including electronic communications, to stimulate the development of digital economy in Ukraine, which establish new mechanisms to influence unscrupulous participants and stimulate IT-business, means of combining government regulation with selfregulatory properties of digital entrepreneurship) (The Verkhovna Rada's law 2020; Draft Law of Ukraine 2020). However, it is not envisaged to supplement the Commercial Code of Ukraine with key provisions on the purpose, content, means of economic and legal policy of the state on the digitalisation of relations in the economy as the core on which such a policy should be based (The Commercial Code of Ukraine 2020). The Ukrainian legislator ignores the relations with the participation of virtual entities (virtual enterprises in particular), the specific features of regulating the relations of economic competition with their participation and with the use of Internet platforms, etc.

In general, the task of the state on digitalisation, the purpose of economic and legal policy of the state in this area, the means to be used, the system of authorised bodies are not defined at the level of law (despite the establishment of the Ministry of Digital Transformation in 2019) (Resolution of the Cabinet of Ministers of Ukraine 2019). This situation does not allow for an adequate comprehensive regulation of digital relations, which is extremely important in the modern period, does not promote transparency of legislation on the relations of the digital economy and, consequently, does not ensure its comprehensibility for most citizens who need to know about their digital rights, mechanisms of their exercise and protection in conditions of quarantine measures caused by the coronavirus pandemic, and forced (for many) use of digital assets (online implementation of most business and domestic operations). This complex task also requires taking into account international experience, in particular the new EU digital strategy for the next five years (EU's new Digital Strategy 2020), as well as the 
experience of countries with the state of the digital economy and its legal and organisational support that are much better than in Ukraine (for example, the United Kingdom) (UK Digital Strategy 2017; Digital Economy Act 2017).

Despite the difficulty of ensuring optimal regulation of relations in the digital economy, delays in resolving this issue are unacceptable given the rapid growth of abuses of digital technologies, as well as the growing need for the use of these technologies for the public benefit and to meet the interests of citizens and businesses in terms of limiting traditional communication (both private and business interaction). The state must determine the content of its economic and legal policy in the field of digitalisation, its strategic and tactical objectives, as well as the means of their implementation. The Commercial Code of Ukraine will be useful, which can enshrine relevant provisions, in particular the strategic objectives of the state (ensuring the social orientation of digitalisation by stimulating the use of digital technologies for public benefit, minimising the risks of digitalisation and creating barriers to digital abuse, involving mechanisms co-regulation with digital business entities and their self-regulatory organisations), tactical tasks (timely response to current needs of digitalisation and digital economy in particular and the emergence of new threats), extensive use of civil society institutions in solving key tasks of digitalisation through various forms of cooperation between government and business (publicprivate partnership, the establishment of special business regimes for digital business entities implementing priority socially significant projects).

\section{THE PROBLEM OF THE CORRELATION OF STATE REGULATION WITH SELF-REGULATION IN THE DIGITAL ECONOMY}

Ideally, state regulation and self-regulation are mutually beneficial phenomena and should be combined to a greater or lesser extent depending on the scope, purpose, limits of regulation, and their forms. Self-regulation in the digital economy ensures a rapid response to the challenges that arise in the national economy. The synergy of self-regulation and management leads to the emergence of new forms and phenomena, in particular relations in the digital economy. State regulation of the digital economy is the response of states, which are also in modern conditions under the influence of transformational selfregulatory processes, to spontaneous self-regulation in the use of information technology related to business processes. At present, there is a tendency that the rate of change, which is attributed to self-regulatory processes, will only increase and state regulation will lag behind (Vinnyk et al. 2020). The state has a duty to protect human and civil rights in the digital age. The speed of technological change obliges the state to take actions and reactions that would have a pre-emptive effect. Modern state regulation of the economy can be defined as follows: direct state regulation; the allocation or delegation of functions of the state to other entities; creating conditions for the establishment of selfregulation and co-regulation institutions (Bakalinska, Belianevych and Honcharenko 2020). Therefore, comprehensive regulation with the participation of the state and self-regulatory entities provides an opportunity to quickly and effectively respond to rapid changes in the digital economy with its inherent needs and risks.

The digital economy relations are based on clearly defined standards for the implementation of certain technological schemes, which are developed in most self-regulatory institutions, the business entities themselves. There is a creation of self-regulatory organisations in new areas, industries, economic activities. The tasks of the state are to establish the legal field of activity of such entities, as well as the provisions they develop. Rules developed by businesses for use in the provision of services are becoming increasingly important; therefore, the establishment of restrictions on both regulatory (standards, rules of service, codes of ethics, etc.) and institutional self-regulation (self-regulatory organisations) indicates the effective operation of public authorities. By delegating authority to selfregulatory organisations, the state can organise the activities of economic entities in the digital sphere. For business entities themselves, it is important to have a softer, understandable rule-making process based on their experience. However, the general principles and priorities of the development of the welfare state must be preserved in the regulation and restrictions of economic activity and keep functioning as fundamental imperatives, such as compliance with competition law, consumer protection, etc. Therefore, the establishment of restrictions on the activities of economic entities, bringing them to justice for violations of competition law is one of the areas of state regulation of the digital economy.

Currently, Ukraine has problems with the establishment of basic infrastructure in the Internet environment (for example, protection of privacy, 
databases), the security of transactions, etc. It is quite possible to regulate these issues with the help of additional regulation by a separate professional community, public organisations and self-regulatory organisations. At the same time, it is necessary to understand the negative aspects of monopoly (dominant) regulation of self-regulatory organisations (hereinafter referred to as "the SROs") in the digital economy. Along with the issue of self-regulation, the problem of meta-regulation is considered, which is most broadly studied by F.C. Simon (Simon, 2017). However, this aspect is understudied in Ukrainian science, with most studies focus on advocating for selfregulation of the digital economy. The latter method of "promoting" self-regulation among businesses differs from meta-regulation, as it does not establish mandatory tools for the application of self-regulation. Therefore, it is important to clearly define the mechanisms of interaction between public authorities and SROs.

E-commerce policy priorities evolve with a country's transition through phases of "e-commerce readiness" (Tigre and O'Connor 2002). Ukraine is establishing a strong foundation for the administration of e-commerce services. That is, the state promotes the development of the digital economy and self-regulation within the country. However, the implementation of effective control over self-regulatory statutory and institutional means remains unresolved. The United States and some EU countries have already faced such issues. $\mathrm{H}$. Farrell points to the emergence of "hybrid institutions" when states establish a common framework of rules, which are then implemented by private entities. The author illustrates the example of the EU-US Safe Harbour Agreement on confidentiality between public and private entities in the field of e-commerce (Farrell 2003). Effective co-regulation in the digital economy must be beneficial to both the state, which represents all citizens, and to the representatives of economic entities, i.e., co-regulation is a flexible way to balance public and private interests. At the present stage of Ukraine's development, the most effective regulation of the digital economy would be co-regulation of this area. Co-regulation, on the one hand, would help the development of telecommunications networks, as both the state and businesses would be interested in it, and, on the other hand, it would ensure the participation of the state in the implementation of policies to respect and protect the rights of citizens.

The need to create SROs in the digital economy is usually associated with streamlining, stabilising, and defining rules in this area, giving legitimacy to decisions of both public authorities and regulations established by the SROs, with increasing consumer confidence in services provided by sub-business entities involved in e-commerce. The establishment and development of the SRO system continue in Ukraine. The process of development of self-regulation of the digital economy in Ukraine takes place within the framework of the national process of introduction of the system of selfregulation in economic activity and development of the digital economy. Thus, the Concept of reforming the institution of self-regulation in Ukraine (2019) and the Concept of development of the digital economy and society of Ukraine for 2018-2020 were adopted (Resolution of the Cabinet of Ministers 2018; Order of the Cabinet of Ministers of Ukraine 2020). An action plan for the implementation of the Concept for the Development of the Digital Economy and Society of Ukraine for 2018-2020 was also approved (Action plan 2018). However, none of these documents refers to the development of self-regulation in the digital economy. Therefore, it is advisable to develop and implement a Concept for the development of self-regulation in the digital economy in Ukraine, which would take into account the specifics of the development of SRO rules and standards, codes of ethics in this area, etc. It should also include provisions on SRO activities in the cryptocurrency and blockchain markets.

\section{THE ROLE OF ELECTRONIC PUBLIC REGISTERS IN THE SYSTEM OF ECONOMIC AND LEGAL POLICY OF THE STATE}

Digitalisation is directly related to and introduced by the state digital public registers, which play a vital role in the system of state regulation of the economy. Ukrainian science is gathering new and already known information about the value potential, types and features of the development and functioning of such registers in the system of fundamental instruments of economic and legal policy of Ukraine. One of the basic vectors of the national policy on the digital economy is the sphere of proper development and functioning of electronic public registers. The existence of the need of society and the state in the fight against corruption has prompted the establishment of a system of registers on a modern legal basis. In Ukraine, the Draft Law No. 2110 "On Public Electronic Registers" was adopted in the first reading (2020). The Verkhovna Rada of Ukraine registered draft laws under No. 4303 "On Stimulating the Development of the Digital Economy in Ukraine" and under No. 4305 "On Amendments to the Criminal Legislation on the Special Procedure for 
Investigating Criminal Offences to Ensure Proper Conditions for the Development of the Digital Economy" (2020), modern amendments are being introduced to the Law of Ukraine "On Information Protection in Information and Telecommunication Systems" (2020).

The direction of the national policy of digitalisation of the economy to establish effective mechanisms to protect and implement the right of everyone to access public information requires legal certainty in the use of register information, permitting, administrative, social, and other public services, management and implementation of state regulation. In many successful countries, the consolidation into an effective system of public electronic registers, as foreign experience indicates, has taken place mainly in an evolutionary way. The evolutionary approach allows not only to set direct but also to consider related tasks to combat corruption, ensure e-government, public involvement in the development and implementation of national policy in the field of the digital economy. Ukraine's strategy to establish a system of electronic public registers to combat corruption is considered revolutionary, not evolutionary. The abrupt way of developing a system of electronic public registers is usually accompanied by defects in security and predictability of its operation. This forces the maximum formalisation of requirements for self-control and control in terms of the content of public registers and access to their resources.

Control (state and self-control) over the state of public register resources in Ukraine should be considered unsatisfactory. Thus, the register of legal entities displays irrelevant data. These are economically inactive enterprises in the uncontrolled territory of Donetsk and Luhansk regions. In the presence of legislative regulation of special simplified procedures for liquidation of enterprises with debts by the decision of the owner, such a problem could be solved. For example, subject to the introduction of the appropriate revision in the bankruptcy legislation, such an opportunity can be implemented by the registrar's appeal to the streamlined judicial procedure for the liquidation of such enterprises with the subsequent entry of the relevant information into the register. The situation with the control over the risk assessment upon compiling electronic tax invoices in the context of risky business entities-taxpayers is critical. In fact, only $20 \%$ of all executors of risky business transactions are identified and entered in the relevant register. Corruption in the development of residential and nonresidential objects manifested itself in uncontrolled maintenance in private hands, moreover, abroad, of the register of the State Architectural and Construction Inspection of Ukraine (hereinafter referred to as "the $D A B I ")$, which contained notifications of the start of construction work, information on their scope, location, permission to building an object on a land plot in Ukraine.

"The DABI register has always been a place of corruption for many years. In contrast, the new Construction Register is exclusively owned by the state. Thus, we will be capable of preventing unauthorised access to it, the introduction of incorrect data and the emergence of corrupt schemes," commented the Deputy Prime Minister - Minister of Digital Transformation Mykhailo Fedorov (A new Register 2020). The non-governmental organisation "Laboratory of Legislative Initiatives", upon expressing critical remarks on the draft law on public electronic registers, addressed the insufficient level of security of electronic information interaction. The establishment of an interoperable system of electronic registers carries great risks of illegal interference in such a system. The state must provide guarantees that the rights of the individual will not be violated, and in case of violations, the damage will be compensated (Analytics of the day 2019). One of the guarantees of ensuring the security of electronic information interaction is the proper formalisation of requirements for the implementation of control functions in the field of maintenance of registers and access to their resources for use. The Draft Law "On Public Electronic Registers" defines the principles of control and state supervision in the field of public electronic registers. It prescribes the status of central executive bodies that implement a national policy on state supervision (control) in the field of development and use of national electronic information resources, as well as the holder of a public electronic register as a person authorised to control and manage a public electronic register (Draft Law of Ukraine 2019).

The procedure for exercising control in the field of registers is developed by the Cabinet of Ministers of Ukraine in accordance with the requirements of the laws that established the relevant registers (Draft Law of Ukraine 2019). Thus, the priority way to increase the value potential of digital public registers in the system of economic and legal policy of Ukraine is to achieve effective control over their maintenance and operation. The effectiveness can be increased by singling out the scope of public relations of control that arise in the field of basic public electronic registers, an independent subject of legal regulation of the Law of Ukraine "On 
Public Electronic Registers" (Draft Law of Ukraine 2019). Under this approach, it is advisable to specify the requirements for the control of basic registers and the requirements for the control of additional registers. Requirements should be differentiated, not common to these classification series. In addition, the requirements for the control of basic registers need to be systematically consolidated in legislation.

\section{SOCIAL ORIENTATION OF THE SPHERE OF ELECTRONIC FINANCIAL SERVICES AS ONE OF THE PRIORITIES OF THE ECONOMIC AND LEGAL POLICY OF THE STATE}

The consequences of the global financial and economic crisis due to the global lockdown caused by the spread of acute respiratory disease COVID-19 caused by coronavirus SARS-CoV-2, undoubtedly raise the issue of immediate recovery and modernisation of domestic economic potential of our country through innovative technologies, by spreading digital technologies to various markets for goods, works, and services. Financial services markets are no exception. That is why the outlined issues should become a priority of the state in the development of its policy on the social direction of electronic financial services. An example of the social orientation of efinancial services is the all-Ukrainian presentation of the country's Economic Audit and Vectors of Economic Development until 2030, published on November 6, 2020, which should become the basis for the "National Economic Strategy 2030". As a priority direction for the development of the national macroeconomic policy, these documents make provision for the introduction of financial inclusion as a process of promoting affordable, timely and full access to a wide scope of financial services, disseminating their use among consumers by introducing existing and innovative approaches, including financial awareness and education (Financial inclusion 2018).

In turn, the National Bank of Ukraine (hereinafter referred to as "the NBU") on December 26, 2019, by the decision of the Board of the NBU No. 1010-pw approved the "Strategy for the Development of the Financial Sector until 2025", where financial inclusion is recognised as a strategic direction of the financial sector of Ukraine (Strategy for the development until 2025 2019). Ensuring the country's financial inclusion (namely, the availability of financial services for the population through the spread of information technology) creates new opportunities for both the economy and the state in general, because it stimulates economic growth by expanding opportunities to attract savings and invest in economic development, increases the level of welfare of the population by developing people's entrepreneurial skills, ability to prudently plan personal financial decisions, including drawing up their budget, control of financial accounts, savings, loans, etc. (Hladkykh 2019). The essence of financial inclusion as a driver of economic growth and an important factor of social equality in the modern world are: increasing the availability and level of use of financial services: stimulating the development of payment infrastructure for non-cash transactions, particularly in rural and remote areas; establishing conditions for the development of remote sales channels for financial services; strengthening the protection of the rights of consumers of financial services: development and implementation of the regulation of market behaviour of participants in the financial sector; ensuring transparency of information on financial services and products; protection of depositors and investors; raising the level of financial literacy of the population: conducting informational and educational activities for different target audiences (Strategy for the development until 2025 2019).

Financial inclusion based on digitalisation through the provision of electronic financial services has certain advantages, namely: it allows financial institutions to reduce costs by reducing queues, reduce paperwork, minimise the cost of maintaining separate units, etc. With digital financial inclusion, a considerable number of consumers have the opportunity to strengthen control over intermediaries that use the mechanisms of the remote provision of financial services (mobile and Internet banking), especially in terms of establishing network structures for the provision of financial services (network marketing); develop recommendations for optimising the subjective composition of financial service providers in different segments of the financial market that require increased attention to technological, operational, and communication integration. The strategy to promote financial inclusion in Ukraine should be based on the paradigm of improving the quality of financial services for consumers who already have access to them and expanding the provision of basic financial services to those consumers who do not have access to it at all, mainly through digitalisation processes. In this aspect, an effective tool to increase the level of financial inclusion is the use of new technologies (Verney 2018).

The globalisation of the economy in general and financial globalisation, in particular, have raised issues 
of financial inclusion of society, which are analysed both locally and globally. One of the common indicators of financial inclusion is the presence of a bank account in the adult population. According to the World Bank, at the present stage, $100 \%$ of the level of financial inclusion has already been reached by certain countries, including Denmark, Sweden, Norway, the Netherlands, and Australia. In Ukraine, according to the NBU Chairman, this figure in 2018 was $63 \%$, which is the global average, as more than 138 million Europeans still do not have a bank account (Zakharkin, Boronos, Zakharkina et al. 2019). The analysis of separate problems of maintenance of financial inclusion in Ukraine gives the chance to outline the following directions of their decision: stimulation of distribution of electronic financial services in Ukraine by proper statutory regulation of the specified relations; raising the level of financial awareness of consumers within the implementation of the NBU Financial Literacy Strategy, which makes provision for the development of a single communication platform on financial literacy and the Educational Information Centre based on the NBU (Verney 2018).

The Financial Sector Strategy of Ukraine until 2025, approved by financial market regulators, which aims to ensure further reform and development of the financial sector of Ukraine in accordance with leading international practices and implementation of measures provided by the EU-Ukraine Association Agreement and other international obligations of Ukraine according to the Strategic direction "V. Innovative development" contains strategic goal 2 "Ensuring the development of the FinTech market, digital technologies and regulatory platforms", according to which, the main measures include: ensuring the development of digital technologies, computer design, big data analysis, blockchain, automation, robotics, and the use of artificial intelligence. Thus, digitalisation processes allow any consumer to freely choose a financial service, collect, copy, distribute, process and in any way use public information obtained in electronic form, including to protect their rights and legitimate interests. Proper protection of the rights and legitimate interests of consumers of the financial services market in modern conditions is possible exclusively based on electronic interaction between all participants in the process of providing and receiving such services with the help of IT technologies.

\section{CONCLUSIONS}

The modern economy in the context of digitalisation requires new approaches to state influence on these processes, appropriate adjustment of economic and legal policy of the state, which aims to effectively implement the goals and objectives of digitalisation in the economic sphere, taking into account the benefits and risks of digital technology. In particular, this applies to the timely (usually fairly rapid) response to the challenges posed by digitalisation (the growth of cybercrime, the ambiguity of the use of digital technologies and related threats), as well as the need to promote their socially useful (technology) use. The fundamental principles of economic and legal policy of the state on digitalisation need to be stipulated in law and, first of all, the Commercial Code of Ukraine, including the strategic objectives of the state in this area, the means used, the principles of combining state regulation with self-regulation, the specifics of certain digital resources (public registers, in particular) and priorities for governing relations in certain markets that require special legal mechanisms to protect consumer rights (electronic financial services, etc.).

In addition to supplementing the Commercial Code of Ukraine with these and other provisions, it is also appropriate to adopt the concept of self-regulation in the digital economy of Ukraine, which should determine the specifics of SRO rules and standards, codes of ethics in this area; introduction of a unified legal framework for the creation, operation and information interaction of state, municipal and other digital public registers, cadastres and information systems, the introduction of Diia City pilot projects, as well as maximum formalisation of self-control and control requirements for access to basic public resources; introduction of new legislative incentives, motivations that should stimulate demand and shape the needs for the use of digital technologies among consumers of financial services, as well as ensure the social direction of this area, including in terms of guaranteeing and protecting consumer rights.

\section{REFERENCES}

A New Register of Construction Activities and a Public Portal Have Been Launched. 2020 (https://www.kmu.gov.ua/news/ zapracyuvav-novij-reyestr-budivelnoyi-diyalnosti-tapublichnij-portal)

Accelerating Digital Transformation with Public-Private Partnerships. 2019 (https://www.tech.gov.sg/media/technews/acceleratingdigital-transformation-with-public-private-partnerships)

Action Plan for the Implementation of the Concept of Development of the Digital Economy and Society of Ukraine for 2018-2020. 2018 (https://zakon.rada.gov.ua/laws/show/67-2018$\% \mathrm{D} 1 \% 80 \# \mathrm{n} 250)$

Analytics of the Day: What Is Wrong with the Draft Law on Public Electronic Registers? 2019 (https://parlament.org.ua/2019/ 10/15/analityka-dnya-shho-ne-tak-iz-zakonopreoktom-propublichni-elektronni-reyestry/) 
Bakalinska, Olha, Olena Belianevych and Olena Honcharenko. 2020. "Advocacy of Competition in the Mechanism of State Regulation of the Economy". International Journal of Financial Research 11(1): 425-433. https://doi.org/10.5430/iifr.v11n1p425

Constitution of Ukraine. 2020 (https://zakon.rada.gov.ua/laws/ show/254\%D0\%BA/96-\%D0\%B2\%D1\%80\#Text)

Depscott, Don and Alex Depscott. 2019. Blockchain Revolution. How the Underlying Technology of Bitcoin and Other Cryptocurrencies is Changing the World. Lviv: Chronicle.

Digital Agenda of Ukraine - 2020. 2016 (https://www.slideshare.net/ tsnua/ss-72226573)

Digital Economy Act. 2017 (https://www.legislation.gov.uk/ukpga/ 2017/30/contents/enacted)

Draft Law of Ukraine "On Public Electronic Registers". 2019 (https://w1.c1.rada.gov.ua/pls/zweb2/webproc4_1?pf3511=6 6772)

Draft Law of Ukraine "On Stimulating the Development of the Digital Economy in Ukraine". 2020 (http://w1.c1.rada.gov.ua/pls/ zweb2/webproc4_1?pf3511=70298)

EU's new Digital Strategy for the Next Five Years - Will Europe Become a Trusted Digital Player. 2020 (https://www.whitecase.com/publications/alert/eus-newdigital-strategy-next-five-years-will-europe-become-trusteddigital)

Farrell, Henry. 2003. "Constructing the International Foundations of E-Commerce - the EU-U.S. Safe Harbour Arrangement". International Organization 57(2): 277-306. https://doi.org/10.1017/S0020818303572022

Financial inclusion. 2018 (https://old.bank.gov.ua/control/uk/ publish/article?art_id=3961976)

Heeks, Richard. 2018. "Digital Economy Policy Strategy Brief" (https://www.researchgate.net/publication/334614942_Digital Economy_Policy_Strategy_Brief)

Hladkykh, Dmytro. 2019. "Directions for ensuring financial inclusion in Ukraine". Analytical Note 8: 1-8.

Law of Ukraine "On Amendments to Criminal Legislation Concerning the Special Procedure for Investigating Criminal Offences in order to Provide Appropriate Conditions for the Development of the Digital Economy". 2020 (http://search.ligazakon. ua/l_doc2.nsf/link1/JI03542A.html)

Law of Ukraine "On Information Protection in Information and Telecommunication Systems" in order to ensure appropriate conditions for the development of the digital economy. 2020 (https://zakon.rada.gov.ua/laws/show/80/94-вp\#Text)

Order of the Cabinet of Ministers of Ukraine "On approval of the Concept of Development of the Digital Economy and Society of Ukraine for 2018-2020". 2018 (https://zakon.rada.gov.ua/ laws/show/67-2018-\%D1\%80\#Text)

Resolution of the Cabinet of Ministers "On Approval of the Concept of Reforming the Institution of Self-Regulation in Ukraine". 2018 (https://zakon.rada.gov.ua/laws/show/308-2018-p\#Text)

Resolution of the Cabinet of Ministers of Ukraine "Issues of the Ministry of Digital Transformation". 2019 (https://zakon.rada. gov.ua/laws/show/856-2019-\%D0\%BF\#Text)

Rogers, Jake. 2016. Public-Private Partnerships: a Tool for Enhancing Cybersecurity. Baltimore: Johns Hopkins University.

Simon, Francesca Isabella. 2017. Meta-Regulation in Practice: Beyond Normative Views of Morality and Rationality. New York: Routledge. https://doi.org/10.4324/9781315308913

Steiner, Kristopher. 2018. Total Automation. How Computer Algorithms Change Lives. Kyiv: Our format.

Strategy for the Development of the Financial Sector of Ukraine until 2025. 2019. (https://bank.gov.ua/ua/about/develop-strategy)

The Commercial Code of Ukraine. 2020 (https://zakon.rada. gov.ua/laws/show/436-15\#Text)

The Verkhovna Rada Passed a Law on Electronic Communications. 2020 (https://lb.ua/news/2020/09/30/467118_deputati_ priynyali_zakon_pro.html)

Tigre, Bastos and Pat O'Connor. 2002. Policies and institutions for Ecommerce readiness: What can developing countries learn from OECD experience? Paris: OECD Publishing.

UK Digital Strategy. 2017 (https://www.gov.uk/government/ publications/uk-digital-strategy/uk-digital-strategy)

Verney, Alexander. 2018. "Financial Inclusiveness and Its Determinants", pp. 8-13. In: Socio-Economic Problems of the Modern Period of Ukraine. Lviv: National Academy of Sciences of Ukraine.

Vinnyk, Oksana, Olha Shapovalov, Nino Patsuriia, Olena Honcharenko and Kateryna Yefremova. 2020. "The Problem of Ensuring the Social Direction of the Legislation of Ukraine on the Digital Economy". Asia Life Sciences 1: 133-151.

Zadykhailo, Dmitriy. 2013. Legal Bases of Development and Implementation of Economic Policy of the State. Kharkiv: Yaroslav Mudryi National University of Law.

Zakharkin, Alexey, Vladimir Boronos, Liudmila Zakharkina and Olha Tverezovskaya. 2019. "Financial Inclusion as a Driver of Financial Security of Ukraine". Bulletin of Sumy State University 1: 43-52. https://doi.org/10.21272/1817-9215.2019.1-6

Received on 01-01-2021

DOI: https://doi.org/10.6000/1929-4409.2021.10.46

(C) 2021 Vinnyk et al.; Licensee Lifescience Global.

This is an open access article licensed under the terms of the Creative Commons Attribution Non-Commercial License (http://creativecommons.org/licenses/by-nc/3.0/) which permits unrestricted, non-commercial use, distribution and reproduction in any medium, provided the work is properly cited. 